\title{
Formula Optimization of Feminine Liquid Soap from Garlic (Allium sativum Linn) Extract
}

\section{Ingenida Hadning*, Astri Yunika}

School of Pharmacy, Faculty of Medicine and Health Science, Universitas Muhammadiyah Yogyakarta, Jl Brawijaya, Tamantirto, Kasihan, Bantul, Yogyakarta 55183.

\begin{abstract}
Leucorrhoea is a condition frequently experienced by women. If it is not appropriately treated, it can become a more severe problem. Leucorrhoea is caused by "Candida albicans" fungus infection. Garlic (Allium sativum Linn) has antibacterial and antifungal activity, where garlic can inhibit the growth of the Candida albicans. This study aims to determine the optimal formulation of feminine liquid soap from garlic extract (Allium sativum Linn) with good physical quality; thus, garlic in treating Leucorrhoea can be practically easier. Optimization of liquid soap formulation used carbopol and sodium lauryl sulfate with various concentration variations. The method included organoleptic observation, $\mathrm{pH}$, and specific gravity for onemonth storage to obtain a good physical quality of liquid soap. The result showed that the formula with $10 \%$ sodium lauryl sulfate met the physical quality test requirements of feminine liquid soap; thus, the formulation of feminine liquid soap with $10 \%$ sodium lauryl sulfate was optimal.
\end{abstract}

Keywords: Allium sativum Linn; Candida albicans; Feminine liquid soap; Garlic extract; Leucorrhoea; Physical evaluation

\section{INTRODUCTION}

Leucorrhoea is a symptom of vaginal discharge other than menstrual blood, indicating a disease of the female reproductive organs. ${ }^{1}$ Leucorrhoea can be caused by the infection of Chlamydia trachomatis bacteria ${ }^{2}$, Candida sp fungus ${ }^{3}$, Trichomonas vaginalis parasite 3 , herpes ${ }^{4}$ virus, and hormonal balance disorders. ${ }^{5}$ Candida albicans is part of the normal human flora that occupies the mucous membranes of the mouth, vagina, and intestinal tract. ${ }^{6}$ In pathogenic conditions, this fungus can proliferate and can cause fermentation. Excessive consumption of antibiotics, steroids, and stamina-

\section{Data of article}

Received : 20 Oct 2020

Reviewed : 22 Dec 2020

Accepted : 23 Feb 2021

DOI

10.18196/jfaps.v1i2.10295

\section{Type of article:}

Research enhancing drugs can increase the risk of vaginal discharge. ${ }^{7}$

There are many traditional medicines to treat vaginal discharge, and one of them is to use garlic (Allium sativum Linn). The part of garlic that is believed to have antifungal and antibacterial properties is the essential oil. The content of allyl sulfide or allicin $\left(\mathrm{C}_{3} \mathrm{H}_{5}-\mathrm{S}-\mathrm{SC}_{3} \mathrm{H}_{5}\right)$ in these essential oils can damage cell walls and inhibit bacterial protein synthesis. ${ }^{8}$ It has been proven in a study conducted by Othman et al. (2008) ${ }^{9}$ regarding the effectiveness of garlic extract as an antibiotic in Candida albicans species. The study stated that the garlic extract was effective

\footnotetext{
*Corresponding author, e-mail: ingenida.hadning@umy.ac.id
} 
as an anti-fungal for Candida albicans species at a concentration of $20 \mathrm{mg} / \mathrm{mL}$.

Along with the modernization of the medical world, treatments with the backto-nature method are still widely used. This method uses natural ingredients processed and developed into various kinds of traditional medicines with minimal side effects. This study aims to identify a feminine liquid soap from garlic extract (Allium sativum Linn) with good physical quality.

\section{METHOD}

This study is experimental laboratory research in optimizing the formula for feminine liquid soap from garlic (Allium sativum Linn) extract. This study was conducted at the Research Laboratory of the Faculty of Medicine and Health Sciences, Universitas Muhammadiyah Yogyakarta, for 1 month.

\section{Research Tools and Materials}

The tools used in this study were $10-\mathrm{mL}$ test tubes (Pyrex), 4-ml test tubes (Pyrex), tube raVLs, Erlenmeyer tubes (Pyrex), volume pipettes (Pyrex), analytical scales (Casbee), blender (Philips), filter papers, centrifuge, water bath, vortex, pycnometer (Pyrex), and $\mathrm{pH}$ meter (Mettler toledo).

The materials used in this study were garlic (Allium sativum Linn) obtained from the traditional Gamping market, Tamantirto Village, Kasihan District, Bantul Regency, Yogyakarta Province, aqua dest, citric acid (Brataco), rose oil perfume, sodium lauryl sulfate (Brataco), methylparaben (Brataco), propylparaben (Brataco), propylene glycol (Brataco) obtained from the Pharmaceutical Technology Laboratory of Universitas Muhammadiyah Yogyakarta, disodium hydrogen phosphate (Brataco), and Carbopol 980 (Brataco) obtained from the Technology Laboratory Ahmad Dahlan University Pharmacy.

\section{Determination}

Determination was carried out at the Department of Pharmaceutical Biology, Faculty of Pharmacy, Gadjah Mada University by comparing the plants used in the study with a reference book, "Flora of Java (Spermatophytes Only)" ${ }^{10}$

\section{Making Garlic Extract}

Garlic extract was made with a solvent, aqua dest. One gram of garlic was mixed with $10 \mathrm{ml}$ of aqua dest, then blended using a domestic blender for 1 minute so that the ingredients were smoother and easier to extract. The mixture was vortexed for 10 minutes and allowed to stand at room temperature for 30 minutes. The use of a vortex was to separate the less refined garlic extract. Furthermore, the extract was centrifuged at $3500 \mathrm{rpm}$ for 10 minutes to obtain a filtrate containing garlic extract, and the filtrate was filtered with filter paper to obtain a purer extract. The extract was placed in a water bath at $600^{\circ} \mathrm{C}$ for 15 minutes so that the allicin compound was more soluble with water. The $600^{\circ} \mathrm{C}$ temperature did not damage the allicin compound and was re-vortexed for 1 minute. The mixture was again centrifuged to separate the water produced from the garlic. The garlic extract obtained as a formulation was 10 $\mathrm{ml}$.

\section{Optimization of Liquid Soap Formulations (Vaginal Douche)}

The formula development in this study used ingredients available and often used for liquid soap preparations in general. This study used carbopol 980 and sodium lauryl sulfate. The use of sodium lauryl 
sulfate and carbopol 980 in this study was because the ingredients were easy to obtain and were more widely used in soap preparations than esaflor and viscolam. Viscolam is a material that contains sodium polyacryladdimetyl taurate used as an emulgator and to increase the viscosity of the water phase. ${ }^{11}$ Esaflor $\mathrm{HM}_{22}$ was used as a thickener in cosmetic preparations and as a stabilizer for oil-inwater emulsions. ${ }^{12}$ The pharmaceutical preparation of liquid soap with water as the primary solvent was a good medium to grow microbes quickly. The preservative used in this process was a combination of methylparaben and propylparaben.

After obtaining the garlic extract, the soap's pharmaceutical formulation would be made. First, disodium hydrogen phosphate was dissolved with water at \pm $400^{\circ} \mathrm{C}$; thus, the sodium salt could dissolve completely. If the crystalline powder was not completely dissolved in cold water, disodium hydrogen phosphate was used as a buffering agent. After that, the sodium lauryl sulfate or carbopol 980 was put into a solution of disodium hydrogen phosphate, and was let to expand ( \pm 15 minutes), then stirred homogeneously. Carbopol 980 was dissolved with aqua dest, which had been heated to $\pm 600^{\circ} \mathrm{C}$. After the sodium lauryl sulfate and carbopol 980 expanded or were homogeneous in the disodium hydrogen phosphate solution, the garlic extract was mixed and homogenized.

The citric acid solution was added until a suitable $\mathrm{pH}$ was obtained. The $\mathrm{pH}$ of the skin ranges from 5.0-6.5. ${ }^{13}$ Then, propylparaben and methylparaben were added as preservatives. Before being mixed into the formula, methylparaben and propylparaben were dissolved in 95\% alcohol as they were insoluble in water. Furthermore, propylene glycol was added as a cosolvent so that it can be thoroughly mixed in the preparation. The final stage was the addition of $100 \mathrm{ml}$ aqua dest and the addition of oleum rose as a fragrance.

Table 1. Formula optimization of garlic extract liquid soap

\begin{tabular}{|c|c|c|c|c|c|c|}
\hline Formula & F1 & $F_{2}$ & $F_{3}$ & $\mathrm{~F}_{4}$ & $\mathrm{~F}_{5}$ & F6 \\
\hline Garlic extract & $1 \%$ & $1 \%$ & $1 \%$ & $1 \%$ & $1 \%$ & $1 \%$ \\
\hline Sodium hydrogen phosphate & $0.5 \%$ & $0.5 \%$ & $0.5 \%$ & $0.5 \%$ & $0.5 \%$ & $0.5 \%$ \\
\hline Na Lauril Sulfate & $1 \%$ & $5 \%$ & $10 \%$ & - & - & - \\
\hline Carbopol 980 & - & - & - & $0.1 \%$ & $0.3 \%$ & $0.5 \%$ \\
\hline Propylene glycol & $3 \%$ & $3 \%$ & $3 \%$ & $3 \%$ & $3 \%$ & $3 \%$ \\
\hline Methylparabens & $0.18 \%$ & $0.18 \%$ & $0.18 \%$ & $0.18 \%$ & $0.18 \%$ & $0.18 \%$ \\
\hline Propylparabens & $0.02 \%$ & $0.02 \%$ & $0.02 \%$ & $0.02 \%$ & $0.02 \%$ & $0.02 \%$ \\
\hline Citric acid & $5 \%$ & $5 \%$ & $5 \%$ & $5 \%$ & $5 \%$ & $5 \%$ \\
\hline Oleum Rose & $0.25 \%$ & $0.25 \%$ & $0.25 \%$ & $0.25 \%$ & $0.25 \%$ & $0.25 \%$ \\
\hline Aquadest ad & $100 \mathrm{ml}$ & $100 \mathrm{ml}$ & $100 \mathrm{ml}$ & $100 \mathrm{ml}$ & $100 \mathrm{ml}$ & $100 \mathrm{ml}$ \\
\hline
\end{tabular}

\section{Explanation:}

$F_{1}$ : liquid soap formula with Na lauryl sulfate $1 \% \mathrm{~b} / \mathrm{v}$

$\mathrm{F}_{2}$ : liquid soap formula with $5 \% \mathrm{Na}$ lauryl sulfate $\mathrm{b} / \mathrm{v}$

$\mathrm{F}_{3}$ : liquid soap formula with Na lauryl sulfate $10 \% \mathrm{~b} / \mathrm{v}$

$\mathrm{F}_{4}$ : liquid soap formula with Carbopol $9800.1 \% \mathrm{~b} / \mathrm{V}$

$F_{5}$ : liquid soap formula with Carbopol $9800.3 \% \mathrm{~b} / \mathrm{v}$

F6: liquid soap formula with Carbopol $9800.5 \% \mathrm{~b} / \mathrm{v}$ 
Physical Evaluation of Liquid Soap

The physical evaluation was to test the stability and safety level of liquid soap preparations in a preclinical manner. The physical evaluation included organoleptic observations, $\mathrm{pH}$ measurements, and specific gravity measurements. Organoleptic observations were carried out based on observations of color, odor, and liquid soap dosage form for 4 weeks. $\mathrm{PH}$ measurements were carried out using a $\mathrm{pH}$ meter; the $\mathrm{pH}$ value should be 5.0$6.5 .{ }^{13} \mathrm{pH}$ measurements needed to be repeated to avoid mistakes. Density measurements were carried out using a pycnometer and were carried out at a room temperature of $250 C$. Density measurements also needed to be repeated to avoid mistakes.

\section{RESULTS AND DISCUSSION}

\section{Organoleptic Observation}

Organoleptic observation showed that the formula with the sodium lauryl sulfate produced clear liquid soap, not too viscous, and foamy. Meanwhile, the formula with the carbopol produced a slightly turbid, viscous liquid and not foamy. The results of organoleptic observations of liquid soap are shown in table 2.

Table 2. Organoleptic Observation Result

\begin{tabular}{llllll}
\hline \multirow{2}{*}{ Formula } & \multirow{2}{*}{ Description } & \multicolumn{4}{c}{ Organoleptic week- } \\
\cline { 2 - 6 } & Shape & $\mathbf{1}$ & $\mathbf{2}$ & $\mathbf{3}$ & $\mathbf{4}$ \\
\hline F1 & Color & $\mathrm{LVL}$ & $\mathrm{LVL}$ & $\mathrm{LVL}$ & $\mathrm{LVL}$ \\
& Smell & $\mathrm{G}$ & $\mathrm{C}$ & $\mathrm{C}$ & $\mathrm{C}$ \\
& Foam & + & $\mathrm{G}$ & $\mathrm{G}$ & $\mathrm{G}$ \\
& Shape & $\mathrm{LVL}$ & $\mathrm{LVL}$ & $\mathrm{LVL}$ & $\mathrm{LVL}$ \\
& Color & $\mathrm{C}$ & $\mathrm{C}$ & $\mathrm{C}$ & $\mathrm{C}$ \\
& Smell & $\mathrm{G}$ & $\mathrm{G}$ & $\mathrm{G}$ & $\mathrm{G}$ \\
& Foam & ++ & ++ & ++ & ++ \\
\hline F3 & Shape & $\mathrm{LVL}$ & $\mathrm{LVL}$ & $\mathrm{LVL}$ & $\mathrm{LVL}$ \\
& Color & $\mathrm{B}$ & $\mathrm{B}$ & $\mathrm{B}$ & $\mathrm{B}$ \\
& Smell & $\mathrm{G}$ & $\mathrm{G}$ & $\mathrm{G}$ & $\mathrm{G}$ \\
& Foam & +++ & +++ & +++ & ++ \\
\hline F4 & Shape & $\mathrm{VL}$ & $\mathrm{VL}$ & $\mathrm{VL}$ & $\mathrm{VL}$ \\
& Color & $\mathrm{T}$ & $\mathrm{T}$ & $\mathrm{T}$ & $\mathrm{T}$ \\
& Smell & $\mathrm{G}$ & $\mathrm{G}$ & $\mathrm{G}$ & $\mathrm{G}$ \\
& Foam & - & - & - & - \\
& Shape & $\mathrm{VL}$ & $\mathrm{VL}$ & $\mathrm{VL}$ & $\mathrm{VL}$ \\
& Color & $\mathrm{T}$ & $\mathrm{T}$ & $\mathrm{T}$ & $\mathrm{T}$ \\
& Smell & $\mathrm{G}$ & $\mathrm{G}$ & $\mathrm{G}$ & $\mathrm{G}$ \\
& Foam & - & - & - & - \\
\hline $\mathrm{F} 6$ & Shape & $\mathrm{VL}$ & $\mathrm{VL}$ & $\mathrm{VL}$ & $\mathrm{VL}$ \\
& Color & $\mathrm{T}$ & $\mathrm{T}$ & $\mathrm{T}$ & $\mathrm{T}$ \\
& Smell & $\mathrm{G}$ & $\mathrm{G}$ & $\mathrm{G}$ & $\mathrm{G}$ \\
& Foam & - & - & - & - \\
\hline & & & & &
\end{tabular}

Explanation:

LVL : less viscous liquid

$\mathrm{VL}$ : viscous liquid

C : clear
$\mathrm{T} \quad$ : turbid

$\mathrm{G} \quad$ : garlic

$+/-\quad$ : foam intensity 
The preparation of liquid soap formula containing sodium lauryl sulfate produced clear, not-too-thick, and foamy liquid soap. The higher the sodium lauryl sulfate concentration was, the foamier the soap would be. It was because sodium lauryl sulfate functioned as a detergent or foaming agent due to the saponification reaction. The saponification reaction occurred due to long hydrogen chain bonds $\left(\mathrm{C}_{12}-\mathrm{C}_{18}\right)$ to form an alkaline carboxylate salt (RCOO-Na).

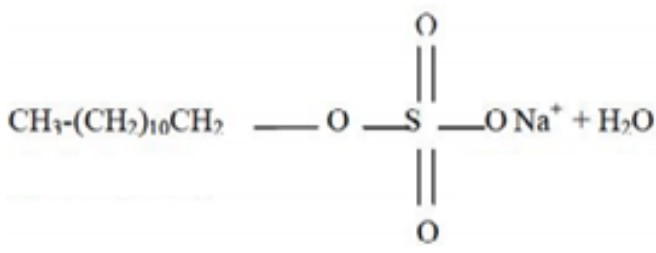

Figure 1. Chemical structure of sodium lauryl sulfate

Whereas in the liquid soap preparation formula containing carbopol, the soap was turbid, thick, and non-foaming. The higher the carbopol concentration was, the thicker the liquid soap preparation would be. Carbopol did not have a hydrogen chain; thus, there was no saponification reaction.<smiles>[R20]C(=O)C([R7])(C)CCC(CC)C(=O)O</smiles>

Figure 2. Chemical structure of carbopol

\section{pH observation}

The result of $\mathrm{pH}$ observation was that there was no significant change during the storage period, where the results were still in the desired $\mathrm{pH}$ range (5.0-6.5). The results of observing the $\mathrm{pH}$ of the preparations are shown in table 3. Based on the results of the $\mathrm{pH}$ test, it shows that all formulas meet the requirements.

Table 3. The result of $\mathrm{pH}$ observation

\begin{tabular}{lllllllllll}
\hline \multirow{2}{*}{ Formula } & \multicolumn{10}{l}{ Average $\mathrm{pH}$ day-(during storage time) } \\
\cline { 2 - 11 } & 1 & 3 & 6 & 9 & 12 & 15 & 18 & 21 & 24 & 27 \\
\hline F1 & 5.42 & 5.43 & 5.44 & 5.44 & 5.44 & 5.44 & 5.45 & 5.45 & 5.45 & 5.46 \\
F2 & 5.43 & 5.52 & 5.52 & 5.53 & 5.54 & 5.54 & 5.54 & 5.54 & 5.55 & 5.55 \\
F3 & 5.44 & 5.44 & 5.46 & 5.47 & 5.47 & 5.47 & 5.47 & 5.47 & 5.47 & 5.47 \\
F4 & 5.53 & 5.53 & 5.53 & 5.54 & 5.54 & 5.55 & 5.55 & 5.55 & 5.57 & 5.57 \\
F5 & 5.56 & 5.57 & 5.58 & 5.58 & 5.58 & 5.58 & 5.59 & 5.59 & 5.59 & 5.62 \\
F6 & 5.53 & 5.53 & 5.54 & 5.54 & 5.55 & 5.56 & 5.56 & 5.57 & 5.57 & 5.58 \\
\hline Comparison & 4.5 & & & & & & & & & \\
\hline
\end{tabular}

\section{Density Measurement}

Density observation during storage time showed no significant changes. However, there were differences in density at each increase in the concentrations. According to the Indonesian National Standard test, the density value specified for liquid soap ranges from $1-1.10 \mathrm{gr} / \mathrm{ml}$ so that the soap can dissolve easily in water and does not leave residues on the skin surface to prevent environmental pollution. ${ }^{14}$ The result of density measurement of the liquid soap preparations is shown in table 4. The density measurement test results show that all formulas, both using sodium lauryl sulfate and carbopol, do not meet the requirements. 
Table 4. Density measurement results

\begin{tabular}{cllllllllll}
\hline \multirow{2}{*}{ Formula } & \multicolumn{10}{c}{ Density (gram / ml) on day- } \\
\cline { 2 - 11 } & 1 & 3 & 6 & 9 & 12 & 15 & 18 & 21 & 24 & 27 \\
\hline$F_{1}$ & 0.962 & 0.968 & 0.970 & 0.967 & 0.969 & 0.970 & 0.970 & 0.970 & 0.970 & 0.970 \\
$F_{2}$ & 0.968 & 0.969 & 0.968 & 0.970 & 0.970 & 0.971 & 0.970 & 0.970 & 0.971 & 0.971 \\
$F_{3}$ & 0.972 & 0.972 & 0.974 & 0.972 & 0.973 & 0.971 & 0.975 & 0.974 & 0.971 & 0.971 \\
$F_{4}$ & 0.967 & 0.969 & 0.970 & 0.970 & 0.970 & 0.970 & 0.973 & 0.972 & 0.971 & 0.971 \\
$F_{5}$ & 0.969 & 0.965 & 0.965 & 0.970 & 0.970 & 0.970 & 0.972 & 0.972 & 0.973 & 0.973 \\
F6 & 0.976 & 0.974 & 0.974 & 0.974 & 0.973 & 0.975 & 0.976 & 0.974 & 0.973 & 0.970 \\
\hline Comparis & 0.99 & & & & & & & & & \\
on & & & & & & & & & & \\
\hline
\end{tabular}

\section{CONCLUSION}

Based on the physical quality test that has been carried out, it can be concluded that the formulation with a $10 \%$ concentration of sodium lauryl sulfate produced feminine liquid soap from garlic extract with good physical quality as it had met the requirements.

\section{ACKNOWLEDGMENT}

This research was supported by Universitas Muhammadiyah Yogyakarta.

\section{CONFLICT OF INTEREST}

The author declares that there is no competing conflicts of interest.

\section{REFERENCES}

1. Mansjoer, A. (2001). Kapita Selekta Kedokteran. Jakarta: Media Aesculapius.

2. Sianturi, M. H. R. (2002). Keputihan Suatu Kenyataan. Jakarta: UI.

3. Dalimartha, S. (2007). Tumbuhan Obat Mengatasi Keputihan. Jakarta: Puspaswara.

4. Kesetyaningsih, T. W. (2003). Prevalensi Trikhomonasis pada Leukhore dan Faktor-Faktor Resiko yang Berhubungan dengan Kondisi Keluarga. Mutiara Medika, 3(2).
5. HaVLer, N. F., \& Moore, J. G. (2001). Esensial Obstetri dan Ginekologi. Jakarta: Hipokrates.

6. Haskel, R., \& Gayford, J. S. (1990). Penyakit Mulut (terj), ed. 2, ECG, Jakarta, pp. 56-61.

7. Sutarmi, R. (2006). Taklukan Penyakit dengan VCO. Depok: Penebar Swadaya.

8. Rustama, M. M., Rahayuningsih, S. R., Kusmoro, J., \& Safitri, R. (2005). Uji Aktivitas Antibakteri dari Ekstrak Air dan Etanol Bawang Putih (Allium sativum L.) terhadap Bakteri Gram Negatif dan Gram Positif. Biotika, 2, pp. 1-8.

9. Fei, L. C., Chen, P. Y. V., Ahmad, Z., Othman, F., \& Pei, C. P. (2008). Antifungal Properties of Allium sativum Extracts On Candida Species. Journal of Medicinal Plants, 9(1).

10. Backer, C. A \& Bakhuizen Van Den Brink. Jr, R. C. (1968). Flora of Java. Vol. I, II \& III. N.V.P. NoordhoffGroningen-The Netherlands.

11. Bakhri, A. S. (2011). Pengaruh Emulgator November Dan Viscolam Terhadap Kestabilan Fisik Krim [skripsi]. Makasar: Universitas Hassanudin Makasar.

12. Marsala, V. (2012). Esaflor HM22. Technical Bulletin. https://asia.incosmetics.com/

13. Wasitaatmadja, S. (1997). Penuntun Ilmu Kosmetik Medik. Jakarta: Universitas Indonesia Press. 
14. Muhammad, A. (2012). Studi Pembuatan Sabun Cair Mangrove Pada Komunitas Wanita Pesisir Griya Karya Tiara Kusuma Rungkut Surabaya [Skripsi]. Malang: Universitas Brawijaya Malang. 